\title{
Shrillness Scattered Society Society and Sociology
}

\author{
Dhivya .A, Kavi nilavu.T, Sinthu.D, Preethika Krishani.G
}

\begin{abstract}
Hitherto the darker sides of the society are hidden treasures which should be brought to light. Identity, culture and language plays a major role in one's life, a human without culture and identity is like our finger without nail. Everyone would come across certain hardships to attain their own identity in their life but only few gets succeeded while remaining people would constantly strive for achieving or lament about it. This paper "SHRILLNESS SCATTERED SOCIETY", under thrust area "SOCIETY AND SOCIOLOGY" predominantly themed about the inequalities and injustice spread over widely in our society. On the whole this paper emphasizes psychoanalytic theory from Shyam Selvadurai's Funny boy.It aims and works for the transformation of Shrillness into cheeriness in their voices.
\end{abstract}

\section{INTRODUCTION}

In our wide world, human beings are the species live in based on the society. Each and every place in our world has their own kind of social norms. So every person follows their own societies and its culture, language, tradition, etc. Later it paved the way for an individual's identity. Identity was created with the help of the language, traditions, culture, etc. The people who migrate from one place to another tend to lose their identity because of the changes in their language and culture. For instance, the African people faced many hardships in America because of their lost their identity. These African people were called as 'Blacks' and the Americans were called as 'Whites' which were solely based on their skin tones. Whites didn't even consider blacks as a human because they lost their own identity and try to follow American's language and culture. These kind of problems raised not only in America but also in several parts of our world. A part of this paper deals with the ethnic conflicts happened in Sri Lanka in between Tamilians and Sinhaleese people and also about the diaspora and homosexuality.

On the whole, the novel brings the struggles of homosexuality, ethnicity and diasporic feelings. The setting of novel is one of the important thing to be noted, which is at the start of civil war between the Sinhalese majority and the Tamil minority, which eventually erupts into a violent one that uproots the family of Arjie. The conflict over belonging can be seen throughout the novel. The two groups fights for their own belonging that who will own the nation and for whom will the government serve.Ethnic Crisis as a

Revised Manuscript Received on September 14, 2019.

Dhivya .A, MA English literature, Sri Krishna Arts and Science College, Coimbatore, Tamilnadu, India. (Email: dhivyaanandh55@gmail.com)

Kavi Nilavu.T, MA English literature, Sri Krishna Arts and Science College, Coimbatore, Tamilnadu, India. Coimbatore, Tamilnadu, India.

Preethika Krishani.G, MA English literature, Sri Krishna Arts and Science College, Coimbatore, Tamilnadu, India. majority. Human beings are categorized their way of living

Sinthu.D, MA English literature, Sri Krishna Arts and Science College,

term designates a sense of collective belonging, which could be based on common descent, language, history, culture, race or religion.the novel explains the violence, the war setting and how the two groups fight. Many people struggled and suffered in this war. It also point outs the government's keen venture to make Sinhala as the only official language.

In Funny Boy ethnic crisis and ethnical conflicts are constantly present, and they play a major part in how the characters live their lives. The theme ethnic conflict is presented from the perspective of the protagonist Arjie, who hardly cares about the ethnicity. In fact, Ethnicity never means anything to Arjie. He never speaks Tamil when he is surrounded by Sinhala friends. Arjie's father figures out the hardship of being a minority Tamil. He concerned their future very much and even changed the language (Sinhalese) classes of his sons at school. Arjie's very first encounter was hearing Ammachi's hatred response towards the Sinhalese. Ammachi's father was murdered by a Sinhalese racist in 1958. At the moment Arjie not only fails to understands what Ammachi was saying, but he also does not get the meaning of the word "racist". The mysterious death of his Daryl uncle who returns after 15 years to Sri Lanka which was first declared as an accident by police but then later found to a murder.

\section{II.METHODOLOGY}

Jegan, a young man and former Tamil Tiger, comes to live with Arjie's family. Jegan is the son of Appa's old friend. There arose a problem. Jegan was falsely accused for plotting an assassination and the quickly released by the police. So, Jegan was suspected by Sinhalese employees in Appa's place. After that incident Appa decides it is best to fire Jegan. Even though Jegan didn't not do any kind of violence, he was treated as a threat. That clearly reflects Sri Lankans serious ethnic insanity in beating to the war. Reader can find many close relationships between the two groups which prove mutual understanding is possible.Arjie's family was saved and helped by Sinhalese neighbours. We can clearly understand the human connections of Sinhalese people who helps in spite of ethnic difference.That was the perfect example that humanity exists and how people never changed themselves because of the political forces. Arjie's father is optimistic and takes decision behalf of the family. Towards the end of the novel we can see the tension between two groups. The important part of the novel which captures various ethnic conflicts and violence was the Epilogue. Towards the end of the story Arjie's father figures that the best chiocefor his family is to leave the place and immigrate to Canada.

Published By: 
The word 'Diaspora' derives from the ancient Greek word "to scatter about" and after some years it was used to explain about the hegira of refugees, language and civilization. In this novel, the protagonist Arjie and his family faced many hard consequences due to the conflicts between Tamil and Sinhalese people. The Sinhalese people were large in number and so eventually they got power to rule over the country and they had all the governing powers too. These Sinhalese were very keen in chasing the Tamilians family to move out from Srilanka. This problem made most of the Tamil people to migrate to other countries. Migrating from their own land to some other foreign land is not an easy task, but because of their political issues they had no other way rather migration. Even Arjie and his family were forced to migrate from Srilanka, it is where the place he grew up happily along with his family. This diasporic matter affected Arjie in a great manner and they tend to lose even their own identity.

\section{III.RESULTS AND DISCUSSIONS}

Homosexuality is neither a disease nor crime, it's just a romantic or sexual attraction between the same genders. However, our living style and circumstances are modernized but the mentality of few people in our society remains too old. Our thinking should also be modernized in some perceptions. Arjie in this novel, was in a great chaotic situation to identify himself and his true identity. People like Arjie were much embarrassed to face the society and they were not supported by their family too.

All it started from their childhood game 'bride-bride'. Arjie used to play the female part well, so all the other girl children wanted him to do that 'bride' role. When his aunt exposed him with the saree draped on his body, one among his family member called him "funny boy" and all others made fun of him. And from that incident, he was warned by his own mother not to play that kind of game anymore, since it was considered as "girls game" and a boy should play "boys game" alone. Arjie was not interested to play the cricket so called "boys game", because it was not his cup of coffee. He was completely lost in his dilemma. Here, high priority were given to the gender roles. While Arjie was unhappy by the way of gender segregation even in games. Arjie's mental health was also affected much because of such incidents.

As soon as Arjie's family came to know about his behavioural change, they tried to change him instead of letting him free to live his own life. Everyone must understand this change is just a hormonal and psychological change. And that's the reason why now the government has given approval legally for homosexuality. At last Arjie found a partner for him named Snegan, but their relationship doesn't last longer. Due to the ethnic conflicts, they were separated in distant lands. But the acceptance of homosexuality should be scattered in the society.

In conclusion, Selvadurai's this novel deals with different genres which makes the readers to think in different perspectives. Each person might have unique kind of thinking but this novel majorly deals with homosexuality issues. Till now in Srilanka, homosexuality is considered to be a criminal offense. Those people were not able to live according to their wish and hesitate to exhibit their identity too. In this novel, all the six chapters have its own moralistic values and clearly explains the pathetic and crucial situations faced by the characters in the novel. In the time of political conflicts, even though the Tamilians were mercilessly killed and beaten up by Sinhalese, there happened an incident which proved that humanity is still alive in this world.

Funny boy is in the perspective of Arjie's narration. He draws the problem of his society and recognition of his own sexuality. Arjie's curiosity is developed when he learns a lesson from his father about the racism and conflicts between Tamil and Sinhalese people. In this novel, he also brings the social issues like homosexuality, diaspora, gender problems, etc. Selvadurai makes Arjie to understand the social conflicts of Sinhalese and Tamil also through the situation of Radha aunty's for Anil. Arjie also breaks his culture and traditional boundaries by being in relationship with Shehan. Here, in this novel psychoanalytic method is used for analyzing the character Arjie. Many people in the world are still in the struggle or in the chaotic state to identify their own self and how to lead a good life for living. But Arjie finally found himself, and aware of his own identity. Selvadurai expresses bittersweet experiences of Arjie throughout the novel. Life is meant to live rather than survive, that must be known to everyone in this world.

\section{CONCLUSIONS}

This paper predominantly focused on the social problems with the psychological approaches. All the human beings are not the same with similar kind of perceptions. People change and their perceptions might also change but the solely constant matter is one's identity. Striving hard for creating our identity is encouraged but at a point of time it should be achieved. Many pity beings were crushed down and treated brutally by our own human species in the name of conflicts and social problems. There are people who still cry loud for their existence in the society. This paper thus conclude the society to treat every human beings without any kind of partialness and instead of shrillness, equality and justice should be scattered in the society.

\section{REFERENCES}

1. Fanon, Frantz. Black Skin, White Masks. New York: Grove Press, 1967. Print

2. Singh, R. P. (2016). Selvadurai, Shyam. In The Encyclopedia of Postcolonial Studies (eds S. Ray and H. Schwarz). doi:10.1002/9781119076506.wbeps323

3. Selvadurai, Shyam. Funny Boy, Haryana, India 122002 : Penguin Publishers, 1994. Print. 